\section{A Blueprint to Integrate and Exploit the Benefits of E- Govemment and BIM in the Urban Heat Planning Process}

GI_Forum 2020, Issue 1

Page: 99 - 106

Short Paper

Corresponding Author: juergen.knies@hs-bremen.de DOI: 10.1553/giscience2020_01_s99

\author{
Jürgen Knies \\ Hochschule Bremen, Germany
}

\begin{abstract}
Against the background of the climate protection plan, the transition of cities towards a renewable heat supply is a particular challenge, involving planning and participation at various levels. In addition simply to the implementation of measures to reduce the heat demand of a building, the question a rises as to the specific role that an individual building can play in strategic energy planning. Strategic energy planning enables a spatial framework for interaction. Communic ationsbetween the building and the planning process have to be established. This paper outlines processes and communic ations between build ing information modelling (BIM) and e-govemment standards in Gemany (XBa u, XFall, XPlanung), and the need for further research and development. The combination and modific ation of existing standards and procedures can create something new in the long term: an indispensable data basisfor munic ipal heat planning.
\end{abstract}

\title{
Keywords:
}

BIM, E-Govemment, XPla nung, heat planning, energy transition

\section{Motivation}

Meeting the targets of the climate protection plan set by the German government is an urgent and pressing challenge. Approximately one third of the energy consumed in Germany is used for room heating and hot water supply (BMWi, 2018). The reduction targets set out in the climate protection plan (BMUB, 2016) differentiate between the various sectors. In the building sector, the aim is to achieve a more or less climate-neutral building stock. This is outlined in the Energy Efficiency Strategy for Buildings issued by the German federal government (Thamling et al., 2015). In the strategy, the reduction of the overall heat requirement and the increased use of renewable heating sources are seen as complementary approaches, with different proportional weighting depending on the scenario in question. The strategy envisages a reduction of the energy demands for water and room heating of between $40 \%$ and 60\% compared to 2008 for buildings used for accommodation, public services and the service sector. For the industrial sector, this figure is set at $20 \%$. The strategy also takes into account building and planning regulations, the difficulties involved in retrofitting, demographic shifts, and the reduction in heat demand due to climate change. Heating 
networks have the potential to integrate renewable energies, into the heating supply system in particular. However, on the basis of the measures that have been implemented to date, it is predicted that the reduction targets cannot be met (Graichen et al., 2017).

Recent developments in the digitalization of the construction industry and of administrative processes, known respectively as building information modelling (BIM) and e-government, as well as the ongoing development of standards and processes relating to the use of geo-data, all offer an unprecedented opportunity to cluster and synergize their respective potentials and take on the challenges of energy transition in urban settings.

This central idea is being heard in the current debate around the concept of the smart city. Given the numerous definitions of, and variety of opinions on, what the 'smart city' actually means (Albino et al., 2015), no attempt will be made here to clarify the issue further.

\section{Energy planning}

In the public discussion, energy transition has largely focused on electrical power supply and taken place outside cities. This is set to change in the near future, with attention turning to urban heat supply - the so-called heat transition. The transformation of the energy supply to entire cities will introduce a new dimension to the planning and participation processes as well as new technological requirements.

A municipal energy plan can indicate the nature of future developments, which are not simply derived from existing funding budgets but also take into account the potential of local sources of renewable energy as well as urban planning data relating to, for example, areas of future or current urban development, demography and mobility. Habermann-Nieße et al. (2012) propose a combination of urban development funding and the funding of energy measures. Such funding could be spatially differentiated by priority areas of energy supply options, which have to be defined from an energy planning perspective.

Municipal heating plans will play a significant role in the future (Schubert, 2015). However, the funding programmes and planning instruments that are currently available are not considered adequate to the task of transforming the energy concept of entire cities: 'The longterm vision to transform urban energy systems is often lacking at the communal planning level' (Riechel, Koritkowski, Libbe, \& Koziol, 2016), and appropriate planning frameworks and standards are not in place. There is more to integrated heating planning than just planning a district heating network. Local conditions and heat supply options of all kinds must be taken into account - for example, the use of heat pumps for individual buildings, LowEx heat networks etc. (Knies, 2018).

Incentives, such as the KfW (German government-sponsored bank dedicated to regeneration projects) programme No. 432, are available. This programme provides consultancy and full planning support for areas which are to be redeveloped and can be combined with the tax incentives granted under German construction law ( $\left.\int 136 \mathrm{BauGB}\right)$ for the implementation of energy efficiency measures (Langenbrinck et al., 2017). Furthermore, regulations and laws can be invoked to enforce connection to and supply from district heating systems. It is very rare, 
however, that such measures are implemented in the context of energetic urban redevelopment and their use remains very controversial (Langenbrinck et al., 2017, p. 84).

Currently, it is difficult to predict the impact of individual, funding-led planning decisions. This is because the funding and its impact on the energetic performance of a building are not recognized as inherent attributes of the building.

\section{Relevant standards}

A variety of standards are in use at the building-planning, urban-planning and implementation levels.

Building Information Modelling (BIM) is seen as a data and process management system, but it is also regarded as the foundation of a new culture of transparency in the construction industry. The individual components of a construction (shell, supply and disposal systems etc.) are all classified according to the Industry Foundation Classes (IFC). Very detailed information can be attached to each element, and this can be of great significance in the overall energetic assessment of a building (e.g. U-value for walls, windows and doors; for more details see http://www.buildingsmart-tech.org/specifications/ifc-releases/ifc4-add2). A comprehensive guide can be found in the German-language handbook Anwenderbuch Datenaustausch BIM/IFC (Liebich \& Hoffeller, 2006). Certain parameters are important input variables for the purposes of GIS visualizations. However, to date, BIM/GIS interaction has mainly consisted in data exchange for structural engineering projects and exploring 3D-GIS visualization possibilities (Barbato et al., 2018), which has led the way to some very complex approaches towards city information modelling (Xu et al., 2014). Agugiaro et al. (Agugiaro, Benner, Cipriano, \& Nouvel, 2018) examine the spatial commonalities between the levels covered by BIM, CityGML and INSPIRE, and demonstrate that the greatest commonalities in coverage are between BIM and CityGML. The authors also describe (ibid.) the Energy Application Domain Extension for CityGML (Energy ADE), which aims to include relevant energy data across an urban area and make it available for simulation purposes.

Work is currently in progress to incorporate an IT-driven process view in urban planning. The main standards under consideration here are XBau and XPlanung (IT-Planungsrat, 2017; Krause \& Munske, 2016). Building application processes and notifications which have been standardized by XBau and are based on the XÖV process standards can be used as BIM data, thus enabling a seamless digital process (Krause, 2018).

To facilitate applications for the energetic funding mentioned above, the continued development of XFall for building applications is strongly recommended (http://xfall.eu/). $\mathrm{XFall}$ is a universally interoperable standard for application data and can be used for centralized application platforms that meet the requirements of the EU Services in the Internal Market Directive (2006/123/EG). XFall is used to transmit application documents and attachments, signatures, status information, information updates and interim reports etc. It could be used to process applications not only for KfW-funded building measures but also for grants available under German renewable energy legislation (Erneuerbaren-Energien-Gesetz, 
EEG) and the market incentive programme (Marktanreizprogramm, MAP) targeted at the heating sector.

XPlanung, on the other hand, allows both the loss-free exchange of spatial planning data between different systems and, in conjunction with XBau, the integration of the plane geometry of buildings in the application process (Krause \& Munske, 2016). Since October 2017, the use of XFall, XBau and XPlanung has been obligatory for all planning authorities in Germany.

\section{Combining standards and processes}

The processing of building applications is now digitally continuous thanks to the use of BIM, $\mathrm{XBau}$ and XPlanung, and this can be taken as a model for similarly continuous urban energy planning.

Energetic redevelopment areas or suitability areas for heating options should be integrated as objects in XPlanung, and their objectives should be differentiated and formalized. They are taken into account as an area setting in the further process. Even if an individual building is located outside these areas, the process would proceed.

In addition, rudimentary BIM models of the existing building stock should be available. Due to the extremely varied nature of buildings, it will not be possible to include detailed differentiations, but the aim is to cover all the existing buildings within the city. One possibility is to collect information from heating energy requirement data sources and other available city models. Energy-ADE, mentioned above, would be suitable for this purpose. As soon as the $\mathrm{KfW}$ receives an application for redevelopment funding, for example, the dataset can be updated to include this specific information. Depending on the proposed measures, the data on the building elements in question (windows, exterior walls, roof etc.) or building utilities (heating supply system, photo-voltaic units etc.) can be adjusted and revised. In the course of time, the overall density of data for a given city will increase.

Redevelopment measures change not only the energetic performance of the building in question. Given sufficient spatial density, such alterations can also alter the nature of the area setting by, for example, reducing the heat demand so that a sufficient number of buildings become suitable and available for connection to a low-temperature heat network. Energy suppliers can use this information as a basis for their offers and proposals. In addition, municipalities can promote local developments using targeted public information campaigns. 
Knies

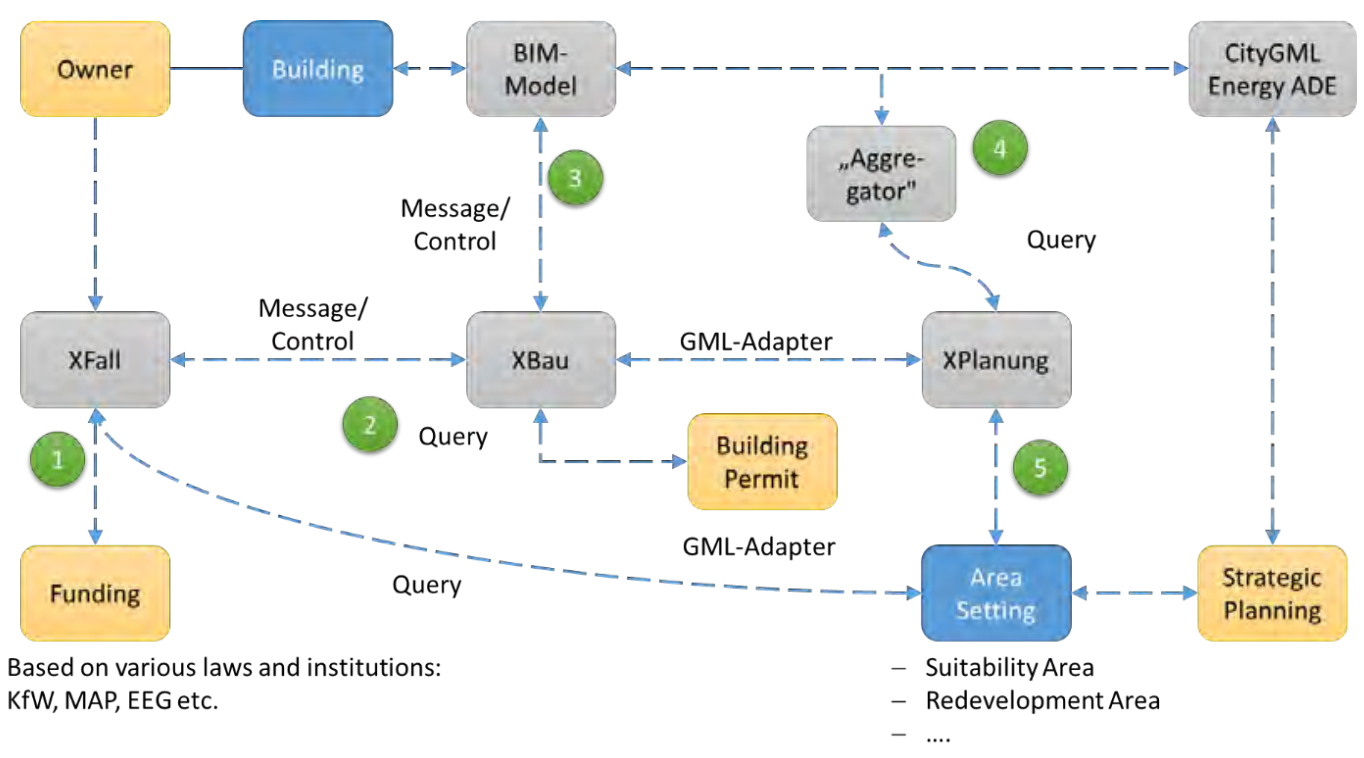

Figure 1: Proposed process cha in - Yellow: actor-related; grey: standards and technical-related; blue: physic al world-related

The following additional developments would also be beneficial in the context of municipal heat planning. (The numbering in the list corresponds to that in Figure 1.) The points listed represent a proposed process scheduling, starting with the initial funding application:

1. Building owners use XFall to apply for funding for energetic redevelopment measures (building components, EEG, MAP). The area setting of the building is automatically taken into account (location in a redevelopment area, in an area of suitability for heat supply options etc.).

2. XFall and XBau then communicate and exchange data, thus integrating energetic measures in the building application documents, as well as requesting information from XBau on any existing building permissions. Energy-related information, e.g. on thermal insulation of the shell and windows at the time of approval, which can be compared with the renovation measures applied for, is particularly relevant here.

3. XBau then communicates with the (rudimentary) BIM model of the building so that changes to the building and energetic data can be recorded upon completion of the redevelopment measures. This assumes, of course, that for all existing buildings a (rudimentary) BIM model exists (and is frequently updated) based on 3D city models (CityGML).

4. Aggregated energetic values are derived from the building model ('Aggregator'), which allow an appropriate heat supply option to be allocated to the building. So, for example, a building which is to be redeveloped and is currently connected to the natural gas supply could, if some further minor alterations were to be carried out to the domestic water system, be suitable for connection to a low-temperature network. Given sufficient spatial density of buildings with similar potential, the borders of the 
redevelopment area can be redrawn to fit and simulations carried out for the whole area, using, for example, Energy-ADE (Agugiaro et al., 2018).

5. Based on the results of the simulation, energetic targets are formalized for the redevelopment areas and areas of suitability in question. These are communicated using XPlanung, and the information is then available for, and can be taken into account in, the funding application process.

The so-called aggregator in Figure 1 has a crucial role in the process. As no further detailed information about a building is required for subsequent strategic planning steps and the use of such data would, in any case, raise data protection issues, the detailed data from the BIM model is aggregated for the purposes of strategic planning. This means that, for any individual building, only a handful of energetic values are actually taken into account. Currently, the aggregator could best be defined using MVD (Model View Definition), which extracts the necessary information in aggregated form and transfers it to, for example, Energy-ADE.

This would allow both the interaction between, and the delineation of, BIM and CityGML to be clearly defined. It would thus enable seamless digital communication throughout the process from the funding application to the building level (BIM), and then to the strategic planning level.

In a subsequent step, detailed technical planning would start, using detailed information from the BIM models. The clear and secure delineation between the data required for strategic planning and those required for detailed technical planning is a delicate and contentious area: more work is required on this issue.

\section{The way ahead}

The approach outlined here is a rough draft and, as such, intended merely as the basis for further discussion on how to enhance existing standards and make use of them in municipal energy planning.

Nearly every necessary component is already there to realize an integrated process chain and to join the strengths of BIM, GIS and e-governmental standards. The lack of interoperability is not really a technical issue, but rather a question of institutional responsibility and competence. Thus the model represents a process chain but deliberately does not allocate responsibilities. This crucial point can best be addressed by the authorities responsible for building permits, funding etc., because it requires an overarching mandate.

The lack of data is a fundamental problem and a real obstacle to strategic energy planning which can only be overcome by continuously adding to the relevant databases. This can only be achieved by integrating and interlocking various standards and data streams with an explicitly spatial component.

The interaction between BIM and CityGML needs further clarification. It must be emphasized that this paper starts from the perspective of the funding of retrofitting measures and, therefore, focusses on the BIM level. Valuable datasets are being built up over time, which can then be incorporated into a CityGML and used to create city-wide perspectives and 
simulations. Implementation takes place at the level of the local area or individual building, and the data from the detailed planning is processed at BIM level, continuing the information loop. In order to eliminate redundant information and inconsistencies, we need to ask at what point in the loop any updates should be carried out. This is not just a technical interface, but a question of responsibilities.

The building stock will, naturally, change over time as rebuilding measures are carried out and recorded in BIM models. It is crucial that the changing potential of an area (neighbourhood, district, suitability area etc.) to be converted to renewable heating be recognized in time. This is possible by continuously updating the energetic value data and, thus, the process of planning appropriate measures can begin in good time. Depending on the spatial distribution of the individual buildings, the extent of areas for redevelopment can be (re-)defined in an energetically rational way.

Probably the most important question is to what extent the funding mechanisms can adapt to, and take into account, the specific surroundings of any given building. A draft bill to the German parliament in 2018 (\$107 GEG Entwurf) addressed this issue. However, this would require current funding policy to be changed in order to accommodate rational spatial differentiation and allow the strengths of various technologies to be combined and matched in spatial clusters.

Currently, planning law does not define any framework for municipal heat planning, so the limits of redevelopment areas and areas of suitability cannot be defined except under urban redevelopment regulations ( $\mathbb{1} 136 \mathrm{BauGB}$ - German federal building regulations). There is a great need for further research into these legal aspects and how planning law would have to be revised. (On planning obstacles, see Riechel et al. (2016).) Any such developments would necessarily impact on the future specifications in XPlanung.

By combining and modifying current standards and processes, something novel can be created: continuous communication from the level of funding to the building itself and, further, to the level of strategic energy planning and the creation of a data resource available as an indispensable tool for decision-makers involved in heat transition at municipal level.

\section{References}

Agugiaro, G., Benner, J., Cipriano, P., \& Nouvel, R. (2018). The Energy Application Domain Extension for CityGML: enhancing interoperability for urban energy simulations. Open Geospatial Data, Software and Standards, 3(1), 30. https://doi.org/10.1186/s40965-018-0042-y

Albino, V., Berardi, U., \& Dangelico, R. M. (2015). Smart Cities: Definitions, Dimensions , Performance, and Initiatives. Journal of Urban Technology, 22(1), 3-21.

H ttps://doi.org/http://dx.doi.org/10.1080/10630732.2014.942092

Barbato, D., Pristeri, G., \& Marchi, M. De. (2018). GIS-BIM Interoperability for Regeneration of Transurban Areas. In M. SCHRENK, V. V. POPOVICH, P. ZEILE, P. ELISEI, C. BEYER, G. NAVRATIL, \& 243 (Eds.), REAL CORP 2018 - EXPANDING CITIES - DIMINISHING SPACE (pp. 243-250). Wien.

BMUB. (2016). Klimaschutzplan 2050 - Kabinettbeschluss vom 14. November 2016 (p. 91). p. 91. Retrieved

from 


\section{Knies}

http://www.bmub.bund.de/fileadmin/Daten_BMU/Download_PDF/Klimaschutz/klimaschutz plan_2050_bf.pdf

BMWi. (2018). Verteilung des Energieverbrauchs nach Anwendungsbereich in Deutschland im Jahresvergleich 2008 und 2016. Retrieved from https://de.statista.com/statistik/daten/studie/253748/umfrage/anteil-der-anwendungsbereicheam-gesamtenergieverbrauch-in-deutschland/

Graichen, P., Peter, F., \& Litz, P. (2017). Das Klimaschutzziel von -40 Prozent bis 2020: Wo landen wir ohne weitere Maßnahmen? (p. 10). p. 10. Retrieved from

https://www.agoraenergiewende.de/fileadmin/Projekte/2015/Kohlekonsens/Agora_Analyse_Klimaschutzziel_2020 _07092016.pdf

Habermann-Nieße, K., Jütting, L., Klehn, K., \& Schlomka, B. (2012). Strategien zur Modernisierung: Mit EKO-Quartieren zu mehr Energieeffizienz; eine Studie. Band 24 Der Schriftenreihe Ökologie, p. 86. Retrieved from: https://www.boell.de/ sites/default/files/Endf_Strategien_zur_Moderisierung_2_kommentierbar.pdf

IT-Planungsrat. (2017). Betriebskonzept XBau / XPlanung, 28.04.2017 / Version 1.0 final (p. 20). p. 20. Retrieved from https://www.itplanungsrat.de/SharedDocs/Downloads/DE/Entscheidungen/23_Sitzung/Standardisierungsage ndaAnlage2.pdf?_blob=publicationFile\&v $=2$

Knies, J. (2018). A spatial approach for future-oriented heat planning in urban areas. International Journal of Sustainable Energy Planning and Management, 16, 3-30. https://doi.org/10.5278/ijsepm.2018.16.2

Krause, K.-U. (2018, February). Xplanung / Xbau Standards des IT-Planungsrates für den Bau- und Planungsbereich: BIM ready. Retrieved from https://www.innovationsforen-bauen40.de/wpcontent/uploads/2018/03/XPlanung-XBau-BIM-Ready.pdf

Krause, K. U., \& Munske, M. (2016). Geostandards XPIanung und XBau. ZFV - Zeitschrift Fur Geodasie, Geoinformation Und Landmanagement, 141(5), 336-342.

https://doi.org/10.12902/zfv-0137-2016

Langenbrinck, G., Rensing, L., Wüllner, L., Klaus Habermann-Nieße, K. K., \& Rosenau, L. (2017). KfW-Programm 432 „Energetische Stadtsanierung - Zuschüsse für integrierte Quartierskonzepte und Sanierungsmanager" Ergebnisse der Begleitforschung (p. 98). p. 98. Retrieved from http://www.bbsr.bund.de/BBSR/DE/Veroeffentlichungen/BBSROnline/2017/bbsr-online-252017-dl.pdf

Liebich, T., \& Hoffeller, T. (2006). Anwenderhandbuch Datenaustausch BIM / IFC (1.1; IAI Industrieallianz für Interoperabilität e.V., Ed.). Retrieved from http://www.ddscad.de/fileadmin/redaktion/PDF-Dateien/buildingSMART-

IFC_Anwenderhandbuch_Version1.0_4MB.pdf

Riechel, R., Koritkowski, S., Libbe, J., \& Koziol, M. (2016). Wärmewende im Quartier - Hemmnisse bei der Umsetzung am Beispiel energetischer Quartierskonzepte (p. 28). p. 28. Retrieved from http://edoc.difu.de/edoc.php?id=FZRP4QJM

Schubert, S. (2015). Die Rolle räumlicher Planung zur Förderung klimaschonender Wärme- und Kälteversorgung in Deutschland und der Schweiz (Dissertation). Verlag Dorothea Rohn, Lemgo.

Thamling, N., Pehnt, M., \& Kirchner, J. (2015). Hintergrundpapier zur Energieeffizienzstrategie

Gebäude (p. 131). p. 131. Retrieved from

https://www.bmwi.de/BMWi/Redaktion/PDF/E/energieeffizienzstrategie-

hintergrundinformation-gebauude.pdf

Xu, X., Ding, L., Luo, H., \& Ma, L. (2014). From Building Information Modeling to City Information Modeling. Journal of Information Technology in Construction (ITcon), 19 (December 2013), 292307. 